\title{
TCOM \\ Avoiding post-truth environmental conflict in New Zealand: communicating uncertainties in endangered species science
}

\section{Anna Palliser and Giles Dodson}

Abstract

Keywords

DOI

Introduction
Keyes [2004, p. 15] says: "In the post-truth era we don't just have truth or lies but a third category of ambiguous statements that are not exactly the truth but fall short of a lie". In this paper about Hector's and Māui dolphin management in New Zealand, we argue that some scientific knowledge about these species presented and disseminated in ways that equate to this third category and as such may be classed as 'post-truth type communication'. This generates citizen mistrust in science, scientists and government agencies and inflames conflict among informed stakeholders. We argue trust may be rebuilt by a combination of deliberative approaches to environmental governance, transparency about uncertainties, information gaps and divergent scientific opinions, and reformulation of normal scientific approaches and assumptions to those advocated by post-normal science.

Environmental communication; Public engagement with science and technology; Science and policy-making

https://doi.org/10.22323/2.18040205

Submitted: 8th March 2019

Accepted: 3rd June 2019

Published: 29th July 2019

In a post-truth world, the boundaries between truth, lies, fact and fiction become increasingly blurred [Keyes, 2019]. When feelings and beliefs are as likely to influence public opinion as scientific facts, trust in the integrity of science is undermined [L. Davis et al., 2018]. Some commentators have argued Science and Technology Studies (STS) has contributed to the post-truth era [Calcutt, 2016 and others, cited in Conway, 2017]; that by critiquing the hegemony of science, exposing the subjectivities involved in the creation of scientific knowedge, STS has risked undermining science [Latour, 2004b; cited in Conway, 2017]. Certainly some have focused attention on scientific uncertainties and subjectivities in order to manufacture distrust in science. For example, the emails resulting in 'climategate' were used by climate change deniers to "provide a misleading and distorted view of science, which deviates from genuine concern over scientific uncertainty" 
[Nerlich, 2010, p. 4] while the tobacco industry manufactured a debate about the accuracy of scientific data linking cancer and tobacco use [Oreskes and Conway, 2011].

However, disclosing the processes involved in science formation and calling for the democratisation of expertise can help navigate the dangers of the post-truth era [Monteiro, 2017]. Conversely, "framing science as a truth in need of restoration" is more likely to contribute to a continuing scepticism towards science [Monteiro, 2017, para 4]. In a similar vein Gluckman [2015] considers trust in science must be earned and the best way to do this is "by playing it straight, being consistent and recognising and labelling our own limits and biases as scientists". Post-normal science (PNS) provides approaches designed to do this [Funtowicz and Ravetz, 2003; van der Sluijs, 2008], as we demonstrate in this paper.

The rise of STS as an academic discipline paralleled the rise of public concern over a panoply of science issues. Issues connected to biotech and medical ethics for example, are increasingly causing concern among citizens and scientists [Moore et al., 2011]. For example, U.S. GMO risk assessments are often undertaken by GMO industries [Nowotny, 2003], while the FDA ${ }^{1}$ have been criticised for allowing pharmaceutical companies to pay FDA regulator salaries [Cohen, 2006]. Given increasing public mistrust in the authority of scientific evidence, along with increasing public scepticism towards scientific impartiality, it becomes important to critically examine the ways science is communicated so that mistrust and scepticism are not further inflamed [L. Davis et al., 2018]. As Lindenfeld et al. [Lindenfeld et al., 2012, p. 29; citing Latour, 2004a] say: “Communication practices are essential within decision making because what knowledge gets counted as valid is as important as the knowledge itself".

Nowhere is this more pertinent than in marine and coastal environmental management, where science is often uncertain and a range of values and perspectives about use and conservation of resources often conflict [Berkes, 2006; Wilson, 2009]. Like Spangenberg [2011], we believe increasing stakeholder participation in environmental decision-making is crucial for rebuilding trust in key public science, but this must be supported by changes to the overall systems of science and governance. Insights from environmental communication scholars about deliberative forms of participatory engagement can help generate meaningful stakeholder participation [Daniels and Walker, 2012], while insights from PNS about approaching the complexities, uncertainties and controversies inherent in environmental problems can help to reformulate systems of science and governance [Funtowicz and Ravetz, 2003]. In this paper we use such insights to examine the management of rare, endemic, New Zealand Hector's and Māui dolphins, looking at ways relevant scientific knowledge is presented and disseminated, alongside related stakeholder perceptions. In recent years the management of these species has been controversial, particularly in relation to the extent and stringency of fishing restrictions used to minimise dolphin threat.

Successive management approaches have evolved within a context of research and knowledge about these dolphin which is incomplete and frequently contested.

Using Hector's and Māui dolphin threat management plans, related literature and research, and interviews from a wide range of New Zealand (NZ) stakeholders, we

\footnotetext{
${ }^{1}$ U.S. Food and Drug Administration.
} 
illustrate how the handling and communication of some dolphin research, which lacks the degree of transparency that could lead to an informed public, is presented in ways that can sway public opinion in the favour of certain perspectives. As our research indicates, handling knowledge in this way contributes to mistrust and conflict between different stakeholder groups and to deepening, rather than ameliorating, public controversy [Senecah, 2004; van der Sluijs et al., 2005]. Specifically, we conclude a lack of transparency about research uncertainties runs the risk of contributing to post-truth types of information transfer and we seek to illuminate how open discussions about research uncertainties and knowledge gaps can reduce post-truth types of knowledge dissemination, mistrust and conflict. We argue that during policy conflict where many voices aim to influence public opinion and decision making, science can maintain a respected position, not by claiming privilege regarding the superiority of its knowledge over other types of knowledge, but by being a voice of integrity [Gluckman, 2015; Jasanoff, 2017; Monteiro, 2017].

\section{Context}

The management of Hector's and Māui dolphins in New Zealand is a complex, conflict-ridden and controversial issue, underpinned by uncertain science [Palliser and Dodson, 2017]. Māui dolphins live off the west coast of North Island, while Hector's are found mainly along the coasts of South Island. Their latest abundance estimates are between 12,000 and 18,500 Hector's [MacKenzie and Clement, 2016] and between 57 and 75 Māui $^{2}$ [Baker et al., 2016]. Set nets (also termed gill nets) are considered to be the major threat to these animals [Manning and Grantz, 2016]. Rules controlling set-netting and trawling, resulting from the 'Hector's and Māui Dolphin Threat Management Plan' (TMP), ${ }^{3}$ have been placed over many coastal areas as a result [Ministry for Primary Industries, 2013] $]^{4}$. Conflict between fishers and conservationists over these rules has been high; fishers argue the stringency of the rules is unjustified and will negatively impact on their livelihoods [Penny et al., 2007], while conservationists consider rules need to be extended to prevent the risk of extinction [Maas, 2017]. This conflict operates at both national and local levels. At the national level, debate continues over the interpretation of dolphin related science, the stringency of fisheries restrictions, and fisheries and endangered species policy. A range of actors are engaged, such as policy makers, regulatory agencies, scientists, NGOs, industry bodies and iwi Māori. The effects of policy are felt locally however and generally local conflict has occurred where dolphin habitat and range and fishing uses overlap and the TMP is in effect, such as the Tāranaki coast and Bank's Peninsula. Likewise, the New Zealand government has to mediate between its important commercial fishing industry and conservation organisations regularly calling for increased protection. From time to time both constituencies seek to engage and influence public opinion on these issues. ${ }^{5}$ Despite concerted scientific effort since the 1980s, uncertainties and knowledge gaps remain [Tyre and Michaels, 2011]. Without scientific consensus and with

\footnotetext{
${ }^{2}$ Māui dolphins are listed as critically endangered.

${ }^{3}$ This is an evolving non-statutory management plan under the auspices of the NZ Department of Conservation (DOC) and Ministry for Primary Industries (MPI) [Ministry for Primary Industries and Department of Conservation, 2012].

${ }^{4}$ The MPI is the New Zealand Ministry for Primary Industries, who are responsible for the commercial fishing industry and other NZ primary industries.

${ }^{5}$ See for instance, https: / / www.nzherald.co.nz/nz/news/article.cfm?c_id=1\&objectid=11271367; https:/ / www.stuff.co.nz/environment/73610305/null.
} 
considerable scientific uncertainty regarding population trends and fishing impacts, research results are prone to criticism from both conservationists and fishers, reducing trust and inflaming conflict.

Extensive public consultation and the use of advisory groups has characterised the TMP. This has included substantial consultation documents, public submissions and agency-led meetings. Initial fishing rules under the TMP were established in 2008 after a year of consultations and information dissemination around New Zealand [Anderton, 2008] and a 2012 TMP review of Māui management resulted in further consultation, and extra rules [Guy, 2013]. In addition, two multi-stakeholder advisory groups, the Māui Research Advisory Group (RAG) ${ }^{6}$ and the Aquatic Environment Working Group (AEWG) ${ }^{7}$ provide information and advice to DOC and the MPI but are not included in decision-making. Despite these clear attempts to involve stakeholders, widespread dissatisfaction with agency decisions and long-term conflict between stakeholder groups remains.

Communicating uncertainty; rebuilding trust
Inherent uncertainties characterise the knowledge informing natural resource management (NRM) [Daniels and Walker, 2012; Wilson and Jacobsen, 2013]. Consequently, decision-making requires science communication that engages citizens in dialogue, rather than 'deficit' approaches relying on information transmission [Lindenfeld et al., 2012]. Trust in science does not appear to have been increased by deficit approaches [Kurath and Gisler, 2009], which appear to undermine the citizen engagement and mobilisation that engenders social change and problem solving [Brulle, 2010]. Senecah [2004] explains how lack of meaningful citizen and stakeholder participation can be a flash point for conflict and discusses how a lack of access (able to engage with understanding and be heard), standing (respect, consideration and esteem given to all perspectives) and influence (to play a meaningful role in decision-making) can result in entrenched distrust of authorities. She argues many common forms of public participation (for example, the New Zealand approaches of consultation and submissions described above) do not fill these criteria. Creating, building and maintaining trust should be the key focus of participatory approaches [Senecah, 2004]. Similarly, others have pointed to the potential for schismogenesis [Bateson, 1935; Brox, 2000; Harrison and Loring, 2014], whereby the relative positions within in environmental conflict become ever more polarised and intractable.

As a discipline, environmental communication has embraced the 'deliberative turn' in public participation theory and practice. As Walker [2007, p. 101] says: "Dialogue fosters learning; learning generates shared understanding, and shared understanding supports deliberation". Deliberation means ideas can be critically examined by stakeholder groups, leading to informed discussions about effective decisions [Walker, 2007; citing Daniels and Walker, 2001]. Daniels and Walker [2012] discuss 'Collaborative Learning', a facilitated deliberative approach to NRM decision-

\footnotetext{
${ }^{6}$ RAG discusses research about Māui dolphins. Includes stakeholders from DOC, MPI, ENGOs, the fishing industry, iwi, academics [Department of Conservation, 2014].

${ }^{7}$ AEWG focuses on fishing impacts on aquatic environments and often meets with the DOC Conservation Service Program Technical Working Group (which examines research about fishing impacts). Stakeholders include DOC, MPI, ENGOs, academics, the fishing industry [Ministry for Primary Industries, 2009]
} 
making based on soft systems thinking, ${ }^{8}$ used successfully for over two decades. However, such approaches are still not common in New Zealand [Eppel, 2014].

The critical emancipatory lens of environmental communication, together with its engagement with effective participatory approaches, means it can make important contributions to sustainability science [L. Davis et al., 2018; Lindenfeld et al., 2012], especially to the 'science of sustainability'. This is a term used by Spangenberg [2011] to describe the type of science needed to understand the complexity of human-environmental systems. Spangenberg [2011] explains this type of science is PNS, a reformulation of science for when issues are complex, knowledge is uncertain, values in dispute and decisions urgent [Funtowicz and Ravetz, 2003]. In such situations normal science knowledge can no longer reliably underpin policy, leading to requirements for deliberative forms of stakeholder involvement and transdisciplinary research, which support effective decision-making under conditions of complexity, uncertainty and controversy. ${ }^{9}$ Central to dialogic and participatory approaches is the recognition that any process supporting the integration or reconciliation of opposing viewpoints must be well-designed from the outset, incorporating specific features, such as trust building, social learning, the integration of differing knowledges, and institutionalisation [Walker, 2007; Reed, 2008]. Indeed, while deliberative, dialogic or participatory approaches should not be seen as a panacea [Conley and Moote, 2003], the adoption of a post-normal science perspective opens up the possibilities of novel approaches, where the incomplete or uncertain nature of normal science can serve as a barrier to conflict resolution.

Many conservation and environmental management challenges arise out of the complex social-ecological systems in which such conflicts are embedded [Anderies, Walker and Kinzig, 2006; Armitage, 2007]. Uncertainties and knowledge gaps, diverse perspectives, understandings and values are normal. Waltner-Towes, Kay and Lister [2008] advocate soft systems approaches for multi-stakeholder decision-making, which aims to find the best rather than the correct way forward, as scientific certainties to underpin decisions are unlikely. Sharing the diverse understandings and values arising from different perspectives is an important step in such approaches, along with critical, reflexive examination of knowledge that may be used to inform policy [Ulrich and Reynolds, 2010].

Kay [2008, p. 31] explains that systems thinking falls in the domain of PNS, saying: "in the world of normal science there is little use for a scheme which cannot say which singular answer is correct!" Normal science evaluates divergent scientific perspectives to choose the most reliable one, which becomes the one presented to policy-makers. However, PNS advocates making the plural, conditional nature of incomplete and uncertain knowledge transparent. In this way dissenting voices and relevant non-scientific bodies of knowledge become available to policy-makers and the public [Stirling, 2010, p. 2]. Tools have been developed to facilitate such spaces, for example the 'pedigree of knowledge' discussed by Craye, Funtowicz and van der Sluijs [2005], which gives citizens the opportunity to discuss with scientists the assumptions, knowledge gaps and uncertainties in their research.

\footnotetext{
${ }^{8}$ Soft systems thinking and methodology focuses on systems of human activity, for example when people come together to make decisions. [see Checkland, 2000].

${ }^{9}$ Which includes researchers from different disciplines as well as from outside the academy [Spangenberg, 2011; Jahn, Bergmann and Keil, 2012].
} 
However, such tools are less effective within a 'normal science' cultural frame. In this case uncertainties may be used strategically by groups to promote their perspectives [van der Sluijs et al., 2005] or divergent perspectives may result in debate about which is true, rather than deliberating all perspectives to find the best way forward. Different perspectives need to be able to 'communicate with one another, influence each other, and reach some sort of coherence' [Petersen et al., 2011, p. 382]. Yet changing a normal science cultural frame into one which accepts and embraces multiple divergent perspectives and learning how to work with these, while making uncertainties transparent, is inevitably a slow transition.

According to Jasanoff [2017]:

Public truths cannot be dictated....neither by a pure, all-knowing science nor unilaterally from the throne of power. Science and democracy, at their best, are modest enterprises because both are mistrustful of their own authority. Each gain by making their doubts explicit.

Citizen questions about knowledge claims, such as who is making them, what is the evidence and what opportunity there has been for criticism and the representation of countervailing arguments, are reasonable and should be answered [Jasanoff, 2017]. Knowledge used for environmental governance requires knowledge holders to declare their values and interests and be open to deliberation regarding knowledge gaps, uncertainties and diverse perspectives [van den Hove, 2007]. Currently such transparency is not the norm in NZ; even when stakeholder participation is enshrined within policies, non-scientific knowledge ${ }^{10}$ may still be marginalised in environmental decision-making, demotivating stakeholder participants, who may 'lose faith in the system and feel fooled' as a result [Linke and Jentoft, 2014, p. 159]. In addition, the approaches used by science to show what has been learned and how it was learned may be opaque to non-experts through the use of disciplinary jargon, dense concepts or complex methods [Wilson and Jacobsen, 2013].

Despite increasing public distrust of science [L. Davis et al., 2018; Moore et al., 2011] underlying societal assumptions within the normal science cultural frame regarding the objectivity and reliability of science, means knowledge presented as 'scientific' can silence concerns. Accordingly, subjective knowledge may be presented as objective or scientific, and coercive rather than deliberative approaches may be used to gain public acceptance of products or policies [Wilson, 2009]. "The desire for scientific answers is great, while the automatic authority of science is a thing of the past" [Wilson, 2009, p. 39]. This illustrates the slow transition from a normal to a PNS cultural frame, which has implications for the success of deliberative forums. The underlying assumptions of participants, their thoughts and beliefs (for example, about science and other forms of knowledge) can undermine important forum parameters, determining, for example, who is silenced or whose knowledge is counted as important [Fischer, 2006; Sprain and Reinig, 2018].

If science is assumed to be the best knowledge, people will try to use it to support their perspectives. This leads to the concept of 'strategic science translation' (SST)

\footnotetext{
${ }^{10}$ For example, the practical wisdom of fishers, local ecological knowledge or indigenous knowledge (for example, mātauranga Māori).
} 
developed by [Cordner, 2015, p. 915] who says "engaging in selective, interpretive or inaccurate SST allows competing stakeholders to bolster their arguments, strengthen their authority and inspire change in policy relevant issues". In other words, if science knowledge confers more authority than other knowledges (or more authority than morals and values) then it will likely be used strategically and selectively when groups disagree. Scientific uncertainty can also be used strategically as reason for inaction or delayed action [Cordner, 2015; citing Oreskes and Conway, 2011]. Even ignorance may be used this way, by avoiding filling knowledge gaps that may undermine products or policies [Kleinman and Suryanarayanan, 2013]. As Fähnrich [2018] has argued, non-science actors, such as activists and NGOs (and other stakeholders) may not be willing to adhere to the norms and value systems of science and science communication. As our research demonstrates, within the 'normal science frame' strategic approaches to handling research and scientific knowledge are to be expected, when complexity, controversy and incomplete science characterise the issues at hand. As such, the likelihood of 'schismogenesis' with environmental or policy conflict is increased [Bateson, 1935; Harrison and Loring, 2014]. Faced with public distrust of science the transition to PNS approaches seems to be an imperative transition [Gluckman, 2015], despite fears that transparency regarding uncertainties and the limitations of normal science may provide ammunition for conflicting groups and further embed the post-truth era. As van der Sluijs et al. [2005, p. 490] argue "Unrealistic expectations of science as a provider of certainties increase the potential for loss of trust" thus fears about misuse of PNS approaches need to be weighed against the risk of increased societal mistrust in science and governance institutions.

Method

The research presents results from an ongoing project focused on how science and other knowledge is handled within contentious environmental management processes. Specifically, the project examines stakeholder participation in management of Hector's and Maui dolphins in New Zealand [Palliser and Dodson, 2017]. The research findings are derived from 51 stakeholder interviews conducted in 2008 and in 2015/2016 as part of this project. This plan was established in 2008 and reviewed in 2012 and is the central management tool for mitigating threats to these dolphins. In the initial stage of the research, interviewees were purposefully sampled on the basis of their involvement in various stakeholder groups on Bank's Peninsula, on New Zealand's South Island. These groups were connected to marine and coastal resource use and conservation. A snowball technique was used to discover and include stakeholders who did not affiliate to these groups but had interests in marine and coastal resource use or conservation. In the second stage of the research $(2015 / 2016)$ interviewees were purposefully sampled on the basis of their involvement in the 2012 TMP review as submitters during the public consultation process. As far as possible, key representatives of differing perspectives and organisations were included.

In 2008 (at the onset of the dolphin threat management planning process) 26 interviews were held with fishers, divers, government agency representatives, conservation NGOs, iwi Māori ${ }^{11}$ and marine wildlife tour operators from the Banks Peninsula area of South Island [Palliser, 2015].

\footnotetext{
${ }^{11}$ Indigenous tribal groups in New Zealand.
} 
Table 1. List of Interviewees, 2015-2016.

\begin{tabular}{|l|l|l|}
\hline Category & Number & Comment \\
\hline DOC representatives & 2 & $\begin{array}{l}\text { Involved in running and reporting on the Māui risk } \\
\text { assessment discussed below }\end{array}$ \\
\hline MPI representatives & 3 & $\begin{array}{l}\text { Including one MPI dolphin researcher and an attendee of } \\
\text { the risk assessment workshop }\end{array}$ \\
\hline Dolphin researchers & 2 & Involved in published abundance estimates work \\
\hline $\begin{array}{l}\text { Conservation NGO } \\
\text { representatives }\end{array}$ & 6 & $\begin{array}{l}\text { NGOs from four different NGOs with connections to } \\
\text { marine environments (on North and South islands) } \\
\text { including Forest and Bird and Seawatch. }\end{array}$ \\
\hline Iwi & 4 & $\begin{array}{l}\text { Including three people recommended by Kaitiaki Rōpu } \\
\text { Invercargill and one from Te Ohu Kaimoana }\end{array}$ \\
\hline Fishers & 7 & $\begin{array}{l}\text { Three on North Island, four in Southland, including a } \\
\text { representative from Egmont Seafood }\end{array}$ \\
\hline $\begin{array}{l}\text { Representative of a N Island } \\
\text { Chamber of Commerce }\end{array}$ & 1 & \\
\hline
\end{tabular}

Table 2. List of Interviewees, 2008.

\begin{tabular}{|l|l|l|}
\hline Category & Number & Comment \\
\hline DOC & 2 & $\begin{array}{l}\text { Local marine ranger and retired long term ranger in } \\
\text { district }\end{array}$ \\
\hline MPI (then Ministry of Fisheries) & 1 & $\begin{array}{l}\text { Overall in charge of commercial fishing in Canterbury } \\
\text { region }\end{array}$ \\
\hline $\begin{array}{l}\text { Akaroa harbor taiapure } \\
\text { representatives }\end{array}$ & 4 & \\
\hline $\begin{array}{l}\text { Akaroa Marine Protection } \\
\text { Society (conservation NGO) }\end{array}$ & 3 & \\
\hline $\begin{array}{l}\text { Akaroa marine wildlife tour } \\
\text { operators }\end{array}$ & 5 & Two current, 3 retired \\
\hline Akaroa commercial fishers & 5 & \\
\hline $\begin{array}{l}\text { Akaroa Recreational } \\
\text { Fishing Club }\end{array}$ & 2 & \\
\hline Local divers & 3 & \\
\hline
\end{tabular}

In 2015 and 201625 interviews with fishers, government agency representatives, iwi Māori, business representatives, dolphin researchers and NGO representatives, from North and South Island NZ were conducted [Palliser and Dodson, 2017]. These interviews were conducted across New Zealand and concerned both the overall TMP and the 2012 review of the Māui dolphin portion of this plan. All interviews were conducted as semi-structured conversations, held either face to face, or in some cases by telephone. Interviews lasted between 30min and 1 hour and were transcribed prior to coding. Interview data was then coded and analysed according to themes emerging from the data. The underlying assumptions during data analysis were those held by post-normal science approaches, i.e. that all that the information and perspectives of all interviewees were legitimate and should meaningfully be incorporated into future approaches to dolphin threat management. 
Given the focus of this paper, the central themes discussed here are stakeholder distrust and the handling of scientific knowledge within the ongoing management of Hector's and Māui dolphins. Other aspects of the findings have been published elsewhere [Palliser and Dodson, 2017]. This paper is explicitly focused on how handling scientific knowledge can contribute to stakeholder conflict. We therefore focus on dolphin abundance estimates and the contestation of these data as this provides specific insight into these issues. Interview data were then contextualised by publicly available policy documents, such as the TMP, relevant published research and other relevant publicly available information, such as news media.

a. Evidence of stakeholder distrust. Conflict regarding the management of Hector's dolphins appears entrenched, dating back to the 1980s, when a marine mammal sanctuary was established to protect Hector's dolphins around Bank's Peninsula on South Island, New Zealand. ${ }^{12}$ From time to time, this conflict re-emerges resulting in significant community tension. Within the sanctuary commercial set-netting was banned and stringent rules were imposed on recreational set-netting [Dawson and Slooten, 1993]. During this period, both Hughey [2000] and Parkin [1996] considered inadequate consultation and negotiation with fishers had alienated this important group, undermining not only dolphin conservation but also wider conservation initiatives. Interviews in the area in 2008, found extreme fisher opposition, both towards fishing rules imposed and towards researchers whose work supported the sanctuary designation [Palliser, 2015]. Fishers felt scapegoated by the public and misrepresented as dolphin-killers. Several mocked the research that had underpinned sanctuary designation, saying it was based on two PhD researchers trying to count dolphins from a small boat, and some spoke of the unwillingness of researchers to engage with fishers. As one interviewee reported:

... at the end of the day my boat is always here, and they really haven't come and asked a lot of questions. And my boat has always been open for them to come out and they haven't. And they've taken an on-line approach to it all... and we sort of say well stuff you, you know (Fisher Interview, 2008).

Fishers and conservationists also voiced extreme distrust of each other as they discussed another long-term and related conflict regarding establishing either a marine reserve ${ }^{13}$ or a taiapure ${ }^{14}$ within the boundaries of the Banks Peninsula sanctuary. One conservationist said the conflict had split the community, with distrust on all sides, and that trying to establish community support for a measure of marine protection was simply too difficult, commenting;

... it's just not something that local communities can do. Nobody in their right mind would take it on, it's just too divisive (Conservationist Interview, 2008).

\footnotetext{
${ }^{12}$ The original sanctuary was etsablished in 1988, and extended in 2008 as a result of the TMP.

${ }^{13}$ In NZ marine reserves are no-take zones for perpetuity. Since 2008 marine protected areas policy has altered the approach to protected area establishment. At the time of the interview, marine reserves were generally established through community campaigns.

${ }^{14}$ Taiapure are Māori fisheries management areas focused on sustainable use rather than no-take protection.
} 
Similarly, a member of the taiapure committee said they would not allow conservationists onto the committee because they found them to be biased and entrenched in their position. Both conservationists and fishers considered the other group had lied and manipulated scientific knowledge to suit their agenda. One conservationist suggested that during this period there was no point using scientific knowledge to argue their case because it was immediately refuted by the opposing group presenting alternative scientific knowledge [Palliser, 2015].

While such extreme conflict may not be the case in other areas of New Zealand, interviews during 2015-2016 strongly suggest continued distrust between conservationist and fisher groups, as well as distrust from both factions towards dolphin scientists and government agencies. Evidence of such distrust, especially in fishers (whose compliance with rules established to protect dolphins is imperative) and conservationists (who contribute to global media outputs through conservation NGOs) is of concern because it may undermine both conservation attempts and the social robustness of policy.

Small-scale coastal fishers interviewed in 2015-2016 reported considerable impact as a result of rules imposed, impacts ranging from complete loss of livelihoods to significant economic loss, as well as grief from losing family businesses. As one fisher reported;

It's killed us. We had a particularly good business; a very good little business running ... Rig quota was trading around about $\$ 15,000$ a tonne prior to any of this malarkey and we were paying $\$ 1.00$ a kilo to lease it. Rig quota now - I had some offered to me recently for $\$ 3,000$ a tonne and we can currently lease it for about .20 cents (Fisher Interviewee, 2015).

Fishers frequently voiced suspicion regarding the validity of some of the research and anger at closures in areas they considered had no dolphins, a position frequently based on long-term observation. They felt disregarded by government agencies and inadequately consulted and informed.

\begin{abstract}
So I have seen one Hector type dolphin since 1986 working on the inshore. I have never seen one [Hector type dolphin] in Taranaki waters. I don't perceive that there is a threat in Taranaki. If these mammals were here I would have to review my stance, but you can't save what isn't there; and that's what we don't seem to be able to get people to understand, that we can't save what isn't here. If they were here we would have to think about what we do... DOC have spent thousands and actually into hundreds of thousands of dollars trying to find a Mäui's [sic] dolphin or a Hector dolphin in Taranaki; plane flights, boat trips, observers and you name it. They can't buy one for love or money; they can't buy one. They haven't got them (Fisher Interviewee, 2015).
\end{abstract}

Conservationists also voiced suspicion about the validity of some dolphin research and considered compliance by fishers with dolphin protection rules was inadequately monitored. One said rules still favoured commercial fishers over dolphin conservation and that fishers had been more than adequately consulted. Other groups such as iwi, had very inadequate consultation. Some of the iwi representatives interviewed were strongly in favour of the rules imposed; however, 
one voiced disapproval over consultation processes because these disregarded the special role of iwi as treaty partners. ${ }^{15}$ This person said;

Well, in the future if something else was set then I would like to think that the iwi or the tangata whenua [indigenous/people of the land] would sit on that board before decisions were made and actually be part of the process of deciding how and when and why and where... you know that would be our take [issue or concern] or our considerations that need to be met. So in the future you know I think we need to be involved from the get-go (Iwi Interviewee, 2015).

\section{b. Dissemination of Hector's dolphin population abundance estimates. A} significant amount of research has been done on these dolphins, with a range of different approaches used to estimate abundance, range, trends, and habits, and how different management scenarios may affect populations [e.g. N. Davis et al., 2008; Gormley et al., 2012; Slooten and Dawson, 2016]. Despite this, reliable estimations of population trends and rate of by-catch have not been established [Tyre and Michaels, 2011]. There have been many abundance estimates since the 1980s, with Table 3 showing all estimates of total Hector's population. ${ }^{16}$ The first paper is a whole of NZ population estimate; the second two together form a whole of South Island estimate, while the final paper is the last of three, which together gives the most recent whole of South Island estimate.

Table 3 appears to show an increasing trend in Hector's abundance and some fisher interviewees voiced confusion about continual talk that the species was heading to extinction when surveys showed it was increasing, at what appeared to some as unusually high rates. Although in general fishers expressed a willingness to engage with research findings, they expressed exasperation at what they perceived to be politicisation of the issue. As one industry representative argued,

The problem... is industry likes a position of just running on science. It is difficult for us to accept that the perceived world is different to the real world and the political world worse than the perceived worl... We have tended always to try and position that we want to work from a science position. And we have trouble because decisions don't always come that way (Fishing Industry Interviewee, 2015).

One Southland fisher had kept his boat and quota ${ }^{17}$ even though he had not been allowed to fish since the 2008 rules came in, ${ }^{18}$ and hoped he would be allowed to fish again as the latest survey shows a significantly higher population than previous estimates. He said:

'So yeah, and you hear figures bandied around about the population of Hector's dolphins now [but] how did they grow that quick if their reproduction rate is so low?! (Fisher Interviewee, 2015)

\footnotetext{
${ }^{15}$ Referring here to the Treaty of Waitangi/Te Tiriti o Waitangi, the partnership treaty between the Crown and Māori rangatira (chiefs) formed in 1840.

${ }^{16}$ These estimates have been chosen as examples to inform the discussion; other abundance estimates not included here are limited to certain areas.

${ }^{17}$ In NZ, under the Quota Management System which manages NZ fisheries, a fisher can buy quota, or the right to harvest a certain percentage of a fished species [Fishserve, 2016].

${ }^{18} \mathrm{He}$ said this was because he loved fishing and it was a family business, passed on from his dad.
} 
Table 3. Total abundance estimates for Hector's dolphins.

\begin{tabular}{|c|c|c|c|}
\hline Date & Citation & Method & Results \\
\hline 1988 & $\begin{array}{l}\text { Dawson \& } \\
\text { Slooten }\end{array}$ & $\begin{array}{l}\text { Boat surveys all } \\
\text { around NZ coast } \\
\text { and interviews } \\
\text { with fishers during } \\
\text { years 1984-88 }\end{array}$ & $\begin{array}{l}\text { Total population on both islands of Hector's and } \\
\text { Māui 3000-4000 animals. No indication of } 95 \% \\
\text { CI (Confidence Interval).* NB at this time the two } \\
\text { subspecies (Hector's and Māui) had not yet been } \\
\text { identified as separate. }\end{array}$ \\
\hline 2004 & $\begin{array}{l}\text { Dawson, } \\
\text { Slooten, } \\
\text { Du Fresne, } \\
\text { Wade \& } \\
\text { Clements }\end{array}$ & $\begin{array}{l}\text { Small boats sur- } \\
\text { veys with some } \\
\text { helicopter work. } \\
\text { South Island pop- } \\
\text { ulation on North, } \\
\text { South and East } \\
\text { coasts (not west } \\
\text { coast) during years } \\
\text { 1997-2000. Survey } \\
\text { mainly to } 4 \text { n.m. } \\
\text { offshore with some } \\
\text { effort out to } 10 \\
\text { n.m. offshore }\end{array}$ & $\begin{array}{l}\text { Hector's dolphin abundance estimate for North, } \\
\text { South and East coast of South Island: } 1880,95 \% \\
\text { CI 1384-2554. }\end{array}$ \\
\hline 2004 & $\begin{array}{l}\text { Slooten, } \\
\text { Dawson \& } \\
\text { Rayment }\end{array}$ & $\begin{array}{l}\text { Aerial surveys of } \\
\text { the West coast, } \\
\text { South Island dur- } \\
\text { ing the year } 2000 . \\
\text { Survey mainly to } 4 \\
\text { n.m. offshore with } \\
\text { some effort out to } \\
10 \text { n.m. }\end{array}$ & $\begin{array}{l}\text { This is the estimate for the west coast of South Is- } \\
\text { land: 5,388 Hector's dolphins. } 95 \% \text { CI } 3613-8034 \text {. } \\
\text { Thus, using the data from the above paper, a total } \\
\text { S. Island population is estimated to be } 7270 \text { anim- } \\
\text { als, } 95 \% \text { CI 5303-9966 }\end{array}$ \\
\hline 2016 & $\begin{array}{l}\text { MacKenzie } \\
\text { \& Clement }\end{array}$ & 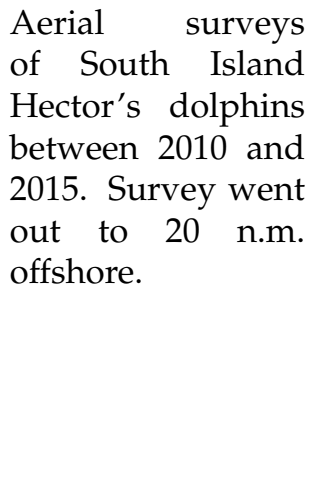 & $\begin{array}{l}\text { This paper gives results for the West coast survey, } \\
\text { the final survey of several, which overall covered } \\
\text { the whole of South Island [for the other surveys } \\
\text { see MacKenzie and Clement, 2013]. } \\
\text { The West coast population was estimated to be } \\
5490 \text { in summer and } 5802 \text { in winter. Drawing this } \\
\text { together with the other surveys the total popula- } \\
\text { tion estimate for South Island became } 14,849 \text { an- } \\
\text { imals, } 95 \% \text { CI } 11,923-18,492 \text {. Therefore, this re- } \\
\text { search estimated the East coast population to be } \\
\text { significantly higher than previous estimates in the } \\
\text { same area. }\end{array}$ \\
\hline
\end{tabular}

$* 95 \%$ CI or $95 \%$ confidence interval is a statistical measure that states a numerical range within which the researchers are 95\% sure contains the actual value. For example, a 95\% CI of 1384-2554 for an abundance estimate means there is $95 \%$ certainty the actual abundance lies within this range.

However, a dolphin researcher interviewee explained an increasing trend could not be established because different methods had been used for each survey. The researcher explained the inherent high uncertainties in abundance estimates means even using the same method each time is unlikely to accurately determine a trend;

... from the scientists point of view getting trends is one of the hardest things to obtain. We wouldn't discuss trends at all unless we had about 40 or 50 years of data and then you are looking at something really large scale so probably in the minds of the scientists that would never be something that we would instigate. Our study was because it 
hadn't been done in 10 years. Even with our study, we can't say if the population has grown because it's just not fine scale enough (Dolphin Research Interviewee, 2016).

Consequently, it is considered better to use the best, most updated methods each time money becomes available for a survey. This leads to both more refined survey results, but incompatibility of methods over time. This information does not appear to have been disseminated beyond the scientific community. In addition, the uncertainties associated with these population estimates and the methodological context are usually not disseminated widely, yet are generally significant for understanding the research findings. Often the median value ${ }^{19}$ is the figure given rather than the range of possibilities indicated by terms such as $95 \% \mathrm{CI}$ - the range within which an estimate is $95 \%$ likely. This makes the median value, and therefore the certainty of scientific knowledge, appear more certain than if the full range of uncertainties was presented [Palliser and Dodson, 2017].

c. Disagreement between researchers. The research also found evidence of significant disagreement between researchers, and stakeholder knowledge being actively shaped by the ways researchers present science to stakeholder audiences. Communication between researchers and ENGOs ${ }^{20}$ can result in ENGOs taking on board researcher opinions as fact. For example, one ENGO interviewee was very disparaging towards the latest Hector's abundance estimates [MacKenzie and Clement, 2016, in Table 3], ${ }^{21}$ speaking of conversations with a university-based researcher who had criticised the latest estimates, and who had asked the International Whaling Commission to investigate them further. Regarding the latest estimates and the IWC's assessment the ENGO interviewee said:

That whole system of how they interpret their data is being examined at the IWC; they have huge concerns about it's about the methodology and its correctness basically (ENGO Interviewee, 2016).

Searching further, we found a radio interview from a local radio station [Raglan Community Radio, 2016], ${ }^{22}$ in which the same university-based dolphin researcher was very critical of the MacKenzie and Clement [2016] estimates and the methods used, saying the research had also been criticised by the IWC:

One of the estimates suggests that there's seven billion Hector's dolphins off the East coast of South Island.... so that's clearly wrong... .so they threw out the results that they don't like... and they take the average of the remaining estimates to come up with an overall average estimate. And among the people who have looked at this work is the Scientific Committee of the International Whaling Commission. And they have said that the decisions that these researchers have made on which of the results to throw out are arbitrary, you know subjective... University-based Researcher, Raglan Community Radio Interview, 2016)

\footnotetext{
${ }^{19}$ Statistical analysis of the range of possible values for the population gives the median value.

${ }^{20}$ ENGO: environmental non-governmental organisation.

${ }^{21}$ Clement and MacKenzie are not university-affiliated researchers; being from the Cawthron Institute, NZ's largest independent science organisation and a private consultancy firm respectively. Their research was contracted by the Ministry for primary Industries, NZ.

${ }^{22}$ Raglan is a small town on the west coast of North Island, with a community that has closely identified itself with Māui dolphins and their conservation.
} 
However, what was not mentioned in the radio interview, and not discussed with the authors by the ENGO interviewee, was the IWC had, in fact, commended the latest estimates, considering them to be good enough to inform management programs [International Whaling Commission, 2016, p. 15]. This is pointed out in a comment from Mackenzie ${ }^{23}$ on the webpage where the interview can be found. ${ }^{24}$ In the radio interview, the university-based researcher also implied MacKenzie and Clements had been pressured by MPI to produce results favourable to the MPI, and saidthe government has a huge PR machine, which scientists cannot hope to compete with,publicising politically valuable dolphin information, whileomitting less favourable information, saying individual scientists cannot hope to compete with such a PR machine.

The MacKenzie and Clement [2016] estimates have been widely disseminated in New Zealand press [e.g. Weber, 2016] and on the MPI website, which says:

Research from the Cawthron Institute in August 2016 estimated the total South Island
population at almost 15,000. This is more than double previous estimates. The research
has been peer-reviewed and endorsed by scientists from the International Whaling
Commission Scientific Committee [Ministry for Primary Industries, 2019].

Notably however, most of the dolphin conservation NGO websites we examined give population estimates for Hector's dolphins of between 5000 and 7000 dolphins [World Wildlife Fund, 2019; Forest and Bird, 2019; Hector's and Maui's dolphins SOS, 2019]. New Zealand Whale and Dolphin Trust [2019] estimates a population of 10, 000 animals, while Project Jonah [2019] a NZ conservation NGO is the only one giving the latest estimate of around 15,000 animals. The Department of Conservation website does not appear to give a population estimate for Hector's dolphins. ${ }^{25}$

A current problem with science is that research which cannot produce definite answers or results, such as the abundance estimates discussed here, cannot easily be distinguished from research that can [Sarewitz, 2016]. The style of presentation is the same, the work is peer reviewed in academic journals and while other scientists may be able to quickly assess the uncertainties in the results, policy-makers and citizens may be less able [Palliser and Dodson, 2017]. This is a critical issue for public communication and engagement with science, especially as it relates to science-for-policy. In our interviews, several fishers, conservationists and one government agency representative criticised dolphin research papers, and voiced distrust of researchers and government agencies, yet none of our interviewees mentioned the uncertainties in the work they discussed. ${ }^{26}$ By presenting research results in the style of 'normal' science, with the uncertainties opaque to the public gaze [Wilson and Jacobsen, 2013], stakeholders assume the median value presented is claiming more certainty than is actually the case. Consequently, when they see the median values for population estimates increasing over the decades, they assume this is an increasing trend. Furthermore,

\footnotetext{
${ }^{23}$ Of MacKenzie and Clement [2016].

${ }^{24}$ See https: / / archive.org/details/DrLizSlootenUnpickingTheMPIHectorsDolphinReport160823.

${ }^{25}$ These websites were checked on 08.10.18.

${ }^{26}$ Interviewees were not asked about uncertainties in research in order to avoid leading questions.
} 
the incompatibility of methods over time is seldom brought to the fore. The implications arising from these uncertainties and inconsistencies, such as the way they underpin the rationale for using different methods for estimating abundance, are understood by dolphin scientists but not by stakeholders. This leaves stakeholders ill-equipped to discuss the data in ways that could lead to socially robust knowledge [Jasanoff, 2017; Risbey et al., 2005] and durable policy measures. In this case, fishers discussed between themselves the apparent discrepancy between the increasing trend and calls for increased dolphin protection from scientists, concluding dolphin scientists had become biased advocates for dolphin conservation. Consequently, fisher trust in dolphin science has been reduced.

When reading dolphin abundance estimate papers, it quickly becomes apparent that the methods employed are too complex to be fully understood by non-experts. Counting dolphins in the wild necessitates considering uncertainties arising from, for example, dolphins being attracted to research vessels, or dolphins being invisible underwater during the survey. It is trying to account for uncertainties such as these, as well as uncertainties arising from decisions about survey patterns (for example the grid pattern to be followed) that generate both the complex statistical calculations seen in these papers and the often broad $95 \%$ confidence intervals that are the final estimates. ${ }^{27}$ It may be unrealistic to expect scientists or knowledge brokers to be able to convey in simple form the whole range of complexity within papers such as these; however, some of the reasons for the complexity and the uncertainty should be clearly explained in ways stakeholders can understand. Gluckman [2017] suggests it is a combination of hubris and a lack of understanding of their need to engage effectively with society, which prevents scientists from including such explanations with their research outputs. Another factor is within the normal science cultural frame, papers that are fully transparent about the uncertainties involved may be less valued by policy-makers [Palliser and Dodson, 2017] and are potentially more open to attack from opponent stakeholder groups. Yet certainly in dolphin management in New Zealand, this needs to be weighed alongside the lack of stakeholder trust in research resulting from a lack of such transparency [van der Sluijs et al., 2005].

Inadequate transparency has also eroded the trust of conservationists. In this case, a researcher voiced doubts about the latest abundance estimates to at least one conservation NGO and during a radio broadcast, criticising the uncertainties involved in the latest estimates but not acknowledging those in earlier estimates. The papers shown in Table 3 illustrate the high uncertainties in both the 2004 and the 2016 results (95\%CI 5303-9966 and 95\%CI 11923-18492 respectively) so that the top of the range in the first estimate lies fairly close to the bottom of the range in the second. Thus explaining the uncertainties in all estimates would have been more beneficial in terms of informing stakeholders and generating socially robust knowledge [van der Sluijs et al., 2005]. Additionally, the radio interviewee did not explain the IWC endorsement of the latest studies. This strong stand against the latest estimates, along with the misleading information about IWC endorsement, could reasonably be expected to lead to public mistrust of the latest estimates, the researchers who produced them and the MPI, who commissioned the research. In addition, well-informed stakeholders are likely to judge the radio interviewee to be

\footnotetext{
${ }^{27}$ During the 2008 TMP development a paper by N. Davis et al. [2008] was considered the TMP Advisory Group to be so complex and impenetrable as to require a supplementary summary. Ultimately the Advisory Group found the results of the analysis to be too uncertain to be usable.
} 
using information strategically to support one perspective, as evidenced by the comments made on the radio website and as discussed by Cordner [2015]. This arguably 'post-truth' style of information dissemination is likely to erode stakeholder trust in dolphin researchers and government agencies.

The radio interviewee said scientists could not hope to compete with government PR machines, so maybe was trying to redress this perceived government bias by selecting information that was biased in the opposite way. Another factor may be that the researcher was operating from a normal science cultural frame, arguing the earlier estimate should be chosen as the most reliable one that should inform policy. However, a PNS frame argues both sets of estimates are important and incomplete understandings, and should be available for deliberation by stakeholders [Stirling, 2010]. Rather than deliberate over which methods, analysis and interpretation is correct, it would be more fruitful to have an open conversation about uncertainties and methodological differences. As Stirling [2010, p. 4] notes: "it is the single definite representations of science that are most vulnerable to political manipulation". A PNS approach would have consciously sought to avoid the further erosion of stakeholder trust resulting from the alignment of conservation NGOs with the perspectives of the radio interviewee. Because this did not happen, the polarisation and conflict between conservationists and fishers is likely to have been inflamed. Conservation NGOs, distrusting the latest estimates, have not mentioned them on their websites, while fishers who see this exclusion from conservation websites, have further reason to distrust conservationists, their knowledge and dolphin researchers. Indeed, at several junctures in the ongoing controversy over dolphin management and the handling of dolphin science, deepening polarisation, or schismogenesis [Bateson, 1935; Harrison and Loring, 2014] is evident. As we have suggested, the maintenance of a 'normal science frame', when a shift to post-normal approaches is warranted, contributes to this polarisation and raises the possibilities of strategic handling and usage of science. Several significant conservation NGO websites, appear to be following the model presented in the radio interview, strategically presenting selected information about Hector's abundance to support their own perspectives. In this way these organisations run the risk of reinforcing the perception of bias. The MPI website shows a firm support for the latest estimate, while DOC, by not mentioning Hector's abundance estimates, is maybe refusing to align with any estimate.

Radio interviews and other forms of media engagement by scientists discussing disagreements between researchers may be valuable for increasing stakeholder understanding, but only if interviewees can accept divergent perspectives [Beebe et al., 2018] and are able to communicate issues of uncertainty and complexity effectively. Gluckman [2017] explains scientists can be both knowledge brokers and advocates, yet should be explicit regarding which roles they are playing and not go beyond their bounds of expertise. In this case the radio interviewee could be criticised on both counts; values, perspectives and science are presented without clear distinctions between them [Wilson, 2009].

It would seem the Hector's and Māui management in NZ has not adequately engaged with calls for increased stakeholder deliberation in complex and controversial environmental management problems. While stakeholder groups such as RAG and AEWG are present, they are excluded from decision-making. These groups make suggestions for future research, which clearly does not address 
the issues we are discussing. Also the perspectives, values and practical knowledge of fishers and conservationists on the ground can only be presented via public submissions, which have been shown to have significant limitations [Senecah, 2004]. Several interviewees said iwi should have been involved at an earlier stage of the decision-making process and early involvement has been shown to increase stakeholder trust in decisions [Glasbergen, 2002]. Indeed, within New Zealand, protocol and processes used in hui ${ }^{28}$ could provide a useful template for stakeholder deliberation approaches [Goven et al., 2012] as could the collaborative learning approach discussed by Daniels and Walker [2012].

Social science researchers, along with other non-science stakeholders, may be reluctant to engage with uncertainties in natural science papers, especially if the ways these are presented are only comprehensible to other natural scientists. However PNS approaches are clear that research used to inform policy should be accessible to well-educated non-experts [Saltelli and Funtowicz, 2014]. Thus it appears timely for a call for environmental and science communication scholarship to engage with the uncertainties in opaque scientific papers, calling for increased transparency regarding uncertainties, knowledge gaps and divergent scientific opinion. In this way science may be able to avoid post-truth style conflicts over contentious science and science-based decision-making and contribute towards rebuilding trust in science.

\section{Conclusion}

It seems that the core of the post-truth type of information discussed here is an unwillingness to engage openly and adequately with the uncertainties inherent in scientific work of this nature, with all parties appearing wary of opening these to the public gaze. Excellent science is producing the best possible estimates of dolphin abundance, but this fact becomes lost in a sea of attempts to shore up inevitable uncertainties. The fear of breaking the illusion of certainty is understandable; if stakeholders and policy-makers understand the uncertainties, knowledge gaps and scientific dispute, some may argue the science has little value [Palliser and Dodson, 2017; Stirling, 2010; van der Sluijs et al., 2005]. Other forms of knowledge, such as local or indigenous knowledge, may enter more forcefully into policy deliberations. However, this has to be weighed against the risk of undermining trust in government institutions and producing knowledge that lacks social robustness [Saltelli and Funtowicz, 2014; van der Sluijs et al., 2005]. In the case of Hector's and Māui dolphin management in New Zealand, open deliberation, conducted in appropriate fora, that acknowledges inevitable uncertainties, knowledge gaps and scientific disagreement is lacking. Instead science outputs hide uncertainties from the public gaze behind opaque statistical methods, while some scientists and NGOs select knowledge that supports their perspectives. This approach risks creating increased conflict between stakeholder groups, increased fisher opposition to conservation initiatives and increased likelihood of post-truth types of information dissemination.

Complex studies, such as the abundance estimates discussed here, provide important contributions to many environmental issues, yet when science is assumed to hold a privileged position, equitable decision-making is undermined

\footnotetext{
${ }^{28}$ Hui are meetings held on marae, Māori land and holdings. They follow certain protocols designed for deliberation of issues.
} 
[Ulrich and Reynolds, 2010]. PNS advocates for deliberating science and other knowledges in equitable ways; however, opaque, complex scientific studies create a barrier to deliberation. Environmental and science communication scholarship must call for such studies to explain uncertainties and assumptions before they are used to inform policy; then with greater transparency about inherent uncertainties, stakeholders can deliberate science knowledge to determine what it can contribute to decision-making.

As discussed widely in the PN-science arena, when only uncertain science is possible, the value of other knowledges is raised and the affected public have the right to examine all uncertain knowledge to determine which best can inform policy [Jasanoff, 2017]. Consequently, public involvement in both knowledge production and the deliberation of knowledge being used to inform management is essential.

Currently in New Zealand the conservation of Hector's and Māui dolphins is being framed as a war to save the species from fishing threats. ${ }^{29}$ It is an issue which has certainly produced entrenched positions. However, conflicts necessitate opponents; framing groups of stakeholders as opponents reduces the likelihood they will work together to share understandings and protect dolphins. Consequently, it may be better to re-frame, to produce and disseminate knowledge that is transparently clear regarding uncertainties, dilemmas, disagreements and knowledge gaps, trusting that the public, governance institutions and scientists can learn new ways to work together with inevitable frustrations and uncertainties, ways that do not resort to 'post-truthing' to promote their perspectives.

\section{References}

Anderies, J. M., Walker, B. H. and Kinzig, A. P. (2006). 'Fifteen weddings and a funeral: case studies and resilience-based management'. Ecology and Society 11 (1). https://doi.org/10.5751/es-01690-110121.

Anderton, J. (2008). Minister's decision letter. URL: https: //www . doc . govt.nz/globa lassets/documents/conservation/native-animals/marine-mammals/maui-tm p/minister-fisheries-decision-letter-tmp-2008.pdf.

Armitage, D. (2007). 'Governance and the commons in a multi-level world'. International Journal of the Commons 2 (1), p. 7. https://doi.org/10.18352/ijc.28.

Baker, C. S., Steel, D., Hamner, R. M., Hickman, G., Boren, L., Arlidge, W. and Constantine, R. (2016). Estimating the abundance and effective population size of Māui Dolphins using microsatellite genotypes in 2015-16, with retrospective matching to 2001-16. Auckland, New Zealand: Department of Conservation. URL: https://www .doc.govt.nz/contentassets/a89a71564d524dd4b7ba69830 cdad7d2/maui-dolphin-abundance-2016.pdf.

Bateson, G. (1935). 'Culture contact and schismogenesis'. Man 35, p. 178. https://doi.org/10.2307/2789408.

Beebe, J. R., Baghramian, M., Drury, L. and Dellsén, F. (2018). ‘Divergent perspectives on expert disagreement: preliminary evidence from climate science, climate policy, astrophysics and public opinion'. Environmental Communication 13 (1), pp. 35-50. https : //doi.org/10.1080/17524032.2018.1504099.

\footnotetext{
${ }^{29}$ Some papers and other articles refer to conservation as a war [e.g. Hulme, 2003; Duffy, 2016].
} 
Berkes, F. (2006). 'From community-based resource management to complex systems: the scale issue and marine commons'. Ecology and Society 11 (1). https://doi.org/10.5751/es-01431-110145.

Brox, O. (2000). 'Schismogenesis in the wilderness: the reintroduction of predators in Norwegian forests'. Ethnos 65 (3), pp. 387-404. https://doi.org/10.1080/00141840050198045.

Brulle, R. J. (2010). 'From environmental campaigns to advancing the public dialog: environmental communication for civic engagement'. Environmental Communication 4 (1), pp. 82-98. https: //doi .org/10.1080/17524030903522397.

Checkland, P. (2000). 'Soft systems methodology: a thirty year retrospective'. Systems research and behavioral science 17 (S1), S11-S58. https://doi .org/10.100 2/1099-1743(200011) $17: 1+<:$ : AID-SRES374>3 . 0.C0;2-0.

Cohen, J. C. (2006). 'Pharmaceuticals and corruption: a risk assessment'. Global Corruption Report, pp. 77-84.

Conley, A. and Moote, M. A. (2003). 'Evaluating collaborative natural Resource management'. Society $\mathcal{E}$ Natural Resources 16 (5), pp. 371-386. https://doi.org/10.1080/08941920309181.

Conway, P. (29th March 2017). 'Post-truth, complicity and international politics'. E-International Relations. URL: https://www.e-ir.info/2017/03/29/post-trut h-complicity-and-international-politics/.

Cordner, A. (2015). 'Strategic science translation and environmental controversies'. Science, Technology, \& Human Values 40 (6), pp. 915-938. https://doi.org/10.1177/0162243915584164.

Craye, M., Funtowicz, S. and van der Sluijs, J. P. (2005). 'A reflexive approach to dealing with uncertainties in environmental health risk science and policy'. International Journal of Risk Assessment and Management 5 (2/3/4), p. 216. https://doi.org/10.1504/ijram.2005.007169.

Daniels, S. E. and Walker, G. B. (2001). Working through environmental conflict: the collaborative learning approach. Westport, CT, U.S.A.: Praeger Publishers.

Daniels, S. E. and Walker, G. B. (2012). 'Lessons from the trenches: twenty years of using systems thinking in natural resource conflict situations'. Systems Research and Behavioral Science 29 (2), pp. 104-115. https://doi.org/10.1002/sres. 2100.

Davis, L., Fähnrich, B., Nepote, A. C., Riedlinger, M. and Trench, B. (2018). 'Environmental communication and science communication - conversations, connections and collaborations'. Environmental Communication 12 (4), pp. 431-437. https://doi.org/10.1080/17524032.2018.1436082.

Davis, N., Bian, R., Starr, P., Lallemand, P., Gilbert, J. and McKenzie, J. (2008). Risk analysis of Hector's dolphin and Maui's dolphin subpopulations to commercial set net fishing using a temporal-spatial age-structured model. (Project code IPA2006/05). New Zealand. https://doi.org/10.13140/rg.2.1.4071.9123.

Dawson, S. M. and Slooten, E. (1993). 'Conservation of Hector's dolphins: the case and process which led to establishment of the Banks Peninsula Marine Mammal Sanctuary'. Aquatic Conservation: Marine and Freshwater Ecosystems 3 (3), pp. 207-221. https://doi .org/10.1002/aqc. 3270030305.

Department of Conservation (2014). Terms of reference for the Māui dolphin research advisory group. URL: https://www. doc.govt.nz/Documents/conservation/nati ve-animals/marine-mammals/mauis/annex-c-maui-rag-tor.pdf.

Duffy, R. (2016). 'War, by conservation'. Geoforum 69, pp. 238-248. https://doi.org/10.1016/j.geoforum.2015.09.014. 
Eppel, E. (2014). Governance of a complex system: water. Institute for Governance and policy studies working paper 14/01. Wellington, New Zealand.

Fähnrich, B. (2018). 'Digging deeper? Muddling through? How environmental activists make sense and use of science - an exploratory study'. JCOM 17 (03), A08. https://doi.org/10.22323/2.17030208.

Fischer, F. (2006). 'Participatory governance as deliberative empowerment: the cultural politics of discursive space'. The American Review of Public Administration 36 (1), pp. 19-40. https://doi .org/10.1177/0275074005282582.

Fishserve (2016). The quota management system and underfishing rights. URL: https: //www.fishserve.co.nz/Media/Default/documents/ACE\%20Information.pdf.

Forest and Bird (2019). Hector's \& Maui's dolphin factsheet. URL: https : / www . forest andbird.org.nz/hectors-mauis-dolphin-factsheet.

Funtowicz, S. and Ravetz, J. (2003). 'Post-normal science'. In: Online Encyclopedia of Ecological Economics. International Society for Ecological Economics.

Glasbergen, P. (2002). 'The green polder model: institutionalizing multi-stakeholder processes in strategic environmental decision-making'. European Environment 12 (6), pp. 303-315. https://doi.org/10.1002/eet. 297.

Gluckman, P. (10th April 2015). Trusting the scientist. URL: http://www.pmcsa.org.nz/blog/trusting-the-scientist/.

- (1st February 2017). Scientific advice in a troubled world. URL: https : //www . pmcsa . org.nz/blog/scientific-advice-in-a-troubled-world/.

Gormley, A. M., Slooten, E., Dawson, S., Barker, R. J., Rayment, W., Fresne, S. du and Bräger, S. (2012). 'First evidence that marine protected areas can work for marine mammals'. Journal of Applied Ecology 49 (2), pp. 474-480. https://doi.org/10.1111/j.1365-2664.2012.02121.x.

Goven, J., Langer, E. R. L., Baker, V., Ataria, J. and Leckie, A. (2012). ‘Community engagement in the management of biosolids: lessons from four New Zealand studies'. Journal of Environmental Management 103, pp. 154-164. https://doi.org/10.1016/j.jenvman.2012.02.007.

Guy, N. (2013). Carter 2012, Minister's decision announcement.

URL: https://www . beehive.govt.nz/release/set-net-restrictions-protec t-maui $\%$ E2\%80\%99s-dolphins.

Harrison, H. L. and Loring, P. A. (2014). 'Larger than life: the emergent nature of conflict in Alaska's Upper Cook Inlet salmon fisheries'. SAGE Open 4 (4), p. 215824401455511. https://doi.org/10.1177/2158244014555112.

Hector's and Maui's dolphins SOS (2019). Hector's and Maui's dolphins SOS webpage. URL: http://www . hectorsdolphins. com/.

Hughey, K. F. D. (2000). 'An evaluation of a management saga: the Banks Peninsula Marine Mammal Sanctuary, New Zealand'. Journal of Environmental Management 58 (3), pp. 179-197. https://doi.org/10.1006/jema.1999.0309.

Hulme, P. E. (2003). 'Biological invasions: winning the science battles but losing the conservation war?' Oryx 37 (2), pp. 178-193. https://doi.org/10.1017/s003060530300036x.

International Whaling Commission (2016). 'Annex M: report of the sub-committee on small cetaceans'. In: Report of the scientific committee (Bled, Slovenia, 7th-19th June 2016).

Jahn, T., Bergmann, M. and Keil, F. (2012). 'Transdisciplinarity: between mainstreaming and marginalization'. Ecological Economics 79, pp. 1-10. https://doi.org/10.1016/j. ecolecon.2012.04.017. 
Jasanoff, S. (2017). 'Perspective. Back from the brink: truth and trust in the public sphere'. Issues in Science and Technology XXXIII (4).

URL: http://issues .org/33-4/perspective-back-from-the-brink-truth-an d-trust-in-the-public-sphere/.

Kay, J. J. (2008). 'Framing the situation: developing a system description'. In: The ecosystem approach, complexity, uncertainty and managing for sustainability. Ed. by D. Waltner-Towes, J. Kay and N. M. Lister. New York, NY, U.S.A.: Columbia University Press, pp. 15-34.

URL: https://www . jstor.org/stable/10.7312/walt13250.5.

Keyes, R. (2004). The post-truth era: Dishonesty and deception in contemporary life. Basingstoke, U.K.: Macmillan Publishers.

- (2019). The post-truth era: dishonesty and deception in contemporary life. URL: https://ralphkeyes.com/book/the-post-truth-era/.

Kleinman, D. L. and Suryanarayanan, S. (2013). 'Dying bees and the social production of ignorance'. Science, Technology, \& Human Values 38 (4), pp. 492-517. https://doi.org/10.1177/0162243912442575.

Kurath, M. and Gisler, P. (2009). 'Informing, involving or engaging? Science communication, in the ages of atom-, bio- and nanotechnology'. Public Understanding of Science 18 (5), pp. 559-573. https://doi.org/10.1177/0963662509104723.

Latour, B. (2004a). Politics of nature: how to bring the sciences into democracy. Cambridge, MA, U.S.A.: Harvard University Press.

Latour, B. (2004b). 'Why has critique run out of steam? From matters of fact to matters of concern'. Critical Inquiry 30 (2), pp. 225-248. https://doi.org/10.1086/421123.

Lindenfeld, L. A., Hall, D. M., McGreavy, B., Silka, L. and Hart, D. (2012). 'Creating a place for environmental communication research in sustainability science'. Environmental Communication 6 (1), pp. 23-43. https://doi.org/10.1080/17524032.2011.640702.

Linke, S. and Jentoft, S. (2014). 'Exploring the phronetic dimension of stakeholders' knowledge in EU fisheries governance'. Marine Policy 47, pp. 153-161. https://doi.org/10.1016/j.marpol.2013.10.010.

Maas, B. (7th June 2017). World's rarest marine dolphin close to extinction. NABU press release. URL: http://www. hectorsdolphins. com/news-releases.html.

MacKenzie, D. and Clement, D. (2013). Abundance and distribution of ECSI Hector's dolphin. Draft New Zealand Aquatic Environment and Biodiversity Report.

- (2016). Abundance and distribution of WCSI hector's dolphin. New Zealand Aquatic Environment and Biodiversity Report 168. Wellington, New Zealand.

Manning, I. and Grantz, K. (2016). Endangered Species Act status review report for Hector's Dolphin (Cephalorrhynchus Hectori). Draft Report to the National Marine Fisheries Service. Office of Protected Resources.

URL: http://www.cio.noaa.gov/services_programs/prplans/pdfs/ID351_He ctors_dolphin_combined\%20comments.pdf.

Ministry for Primary Industries (2009). Terms of reference for the aquatic environment working group. URL: https : / f f . fish. govt.nz/Page . aspx?pk=113\&dk=21906.

- (2013). Management of Hector's and Māui's dolphins factsheet. URL: https://fs.fish.govt.nz/NR/rdonlyres/3F942AD0-FEE7-4796-BAB8-OD BD1ABC1CE9/0/hectorsmauidolphinfactsheetfinal26112013.pdf.

- (2019). Protecting Hector's and Māui dolphins. URL: https://www . mpi .govt.nz/pr otection-and-response/sustainable-fisheries/managing-our-impact-onmarine-life/protecting-hectors-and-maui-dolphins/. 
Ministry for Primary Industries and Department of Conservation (2012). Review of the Maui's dolphin threat management plan. MPI and DOC joint discussion paper no: $2012 / 18$.

URL: https://www. doc.govt.nz/Documents/conservation/native-animals/m arine-mammals/maui-tmp/mauis-tmp-discussion-document-full.pdf.

Monteiro, M. (8th September 2017). Science, politics and (post-)truth.

URL: https://sites.library .queensu.ca/transmissions/science-politics -and-post-truth/.

Moore, K., Kleinman, D. L., Hess, D. and Frickel, S. (2011). 'Science and neoliberal globalization: a political sociological approach'. Theory and Society 40 (5), pp. 505-532. https://doi.org/10.1007/s11186-011-9147-3.

Nerlich, B. (2010). “Climategate': paradoxical metaphors and political paralysis'. Environmental Values 19 (4), pp. 419-442. https://doi.org/10.3197/096327110x531543.

New Zealand Whale and Dolphin Trust (2019). Hector's dolphins. URL: http://whaledolphintrust.org.nz/projects/hectors-dolphins/.

Nowotny, H. (2003). 'Democratising expertise and socially robust knowledge'. Science and Public Policy 30 (3), pp. 151-156. https://doi.org/10.3152/147154303781780461.

Oreskes, N. and Conway, E. M. (2011). Merchants of doubt. How a handful of scientists obscured the truth on issues from tobacco smoke to global warming. New York, U.S.A.: Bloomsbury Press.

Palliser, A. (2015). ‘Building adaptive capacity for sustainable natural resource management: a case study in Akaroa coastal environment, New Zealand'. Doctoral dissertation. Dunedin, New Zealand: University of Otago. URL: http: //hdl . handle. net/10523/5899.

Palliser, A. and Dodson, G. (2017). 'Uncertainty, complexity and controversy in dolphin threat management: a role for post-normal science?' Environmental Science E Policy 78, pp. 74-80. https://doi.org/10.1016/j.envsci.2017.09.004.

Parkin, E. M. (1996). 'The Banks peninsula marine mammal sanctuary: a recreation-conservation conflict'. Unpublished. Master's thesis. Lincoln, New Zealand: Lincoln University. URL: https://hdl . handle.net/10182/2015.

Penny, G., Dumbell, G., Vincent, P. and McEntee, S. (2007). A socio-economic impact assessment of fishers: proposed options to mitigate fishing threats to Hector's and Maui's dolphins. V.1 final report. Auckland, New Zealand.

Petersen, A. C., Cath, A., Hage, M., Kunseler, E. and van der Sluijs, J. P. (2011). 'Post-normal science in practice at the Netherlands environmental assessment agency'. Science, Technology, E Human Values 36 (3), pp. 362-388. https://doi.org/10.1177/0162243910385797.

Project Jonah (2019). Hector's and Maui's dolphins. URL: https: //www. projectjonah . org.nz/Take+Action/Hectors++Mauis+Dolphins.html.

Raglan Community Radio (23rd August 2016). Unpicking the MPI Hector's dolphin report. URL: https://archive.org/details/DrLizSlootenUnpickingTheMPIHec torsDolphinReport160823.

Reed, M. S. (2008). 'Stakeholder participation for environmental management: a literature review'. Biological Conservation 141 (10), pp. 2417-2431. https://doi.org/10.1016/j.biocon.2008.07.014. 
Risbey, J., van der Sluijs, J., Kloprogge, P., Ravetz, J., Funtowicz, S. and Quintana, S. C. (2005). 'Application of a checklist for quality assistance in environmental modelling to an energy model'. Environmental Modeling $\mathcal{E}$ Assessment 10 (1), pp. 63-79. https://doi.org/10.1007/s10666-004-4267-z.

Saltelli, A. and Funtowicz, S. (2014). 'When all models are wrong'. Issues in Science and Technology 30 (2), pp. 79-85.

Sarewitz, D. (2016). 'Saving science'. The New Atlantis 49, pp. 4-40.

Senecah, S. (2004). 'The trinity of voice: the role of practical theory in planning and evaluating the effectiveness of environmental participatory process'. In: Communication and public participation in environmental decision-making. Ed. by S. W. Depoe, J. W. Delicath and M. F. Aepli Eisenbeer. Albany, NY, U.S.A.: State University of New York Press, pp. 13-33.

Slooten, E. and Dawson, S. M. (22nd November 2016). Updated population viability analysis, population trends and PBRs for Hector's and Maui dolphin.

URL: https: //www . regulations . gov/document?D=NOAA-NMFS-2016-0118-0076 (visited on 27th August 2017).

Spangenberg, J. H. (2011). 'Sustainability science: a review, an analysis and some empirical lessons'. Environmental Conservation 38 (3), pp. 275-287. https://doi.org/10.1017/s0376892911000270.

Sprain, L. and Reinig, L. (2018). 'Citizens speaking as experts: expertise discourse in deliberative forums'. Environmental Communication 12 (3), pp. 357-369. https://doi.org/10.1080/17524032.2017.1394894.

Stirling, A. (2010). 'Keep it complex'. Nature 468 (7327), pp. 1029-1031. https://doi.org/10.1038/4681029a.

Tyre, A. J. and Michaels, S. (2011). 'Confronting socially generated uncertainty in adaptive management'. Journal of Environmental Management 92 (5), pp. 1365-1370. https://doi.org/10.1016/j. jenvman.2010.10.014.

Ulrich, W. and Reynolds, M. (2010). 'Critical systems heuristics'. In: Systems approaches to managing change: a practical guide. Ed. by M. Reynolds and S. Holwell. London, U.K.: Springer, pp. 243-292. https://doi.org/10.1007/978-1-84882-809-4_6.

van den Hove, S. (2007). 'A rationale for science-policy interfaces'. Futures 39 (7), pp. 807-826. https://doi.org/10.1016/j.futures.2006.12.004.

van der Sluijs, J. P. (2008). 'Post-normal science and STS'. In: Changing Relations Between Science and Society conference (Utrecht, The Netherlands).

van der Sluijs, J. P., Craye, M., Funtowicz, S., Kloprogge, P., Ravetz, J. and Risbey, J. (2005). 'Combining quantitative and qualitative measures of uncertainty in model-based environmental assessment: the NUSAP system'. Risk Analysis 25 (2), pp. 481-492. https://doi.org/10.1111/j.1539-6924.2005.00604.x.

Walker, G. B. (2007). ‘Public participation as participatory communication in environmental policy decision-making: from concepts to structured conversations'. Environmental Communication 1 (1), pp. 99-110. https://doi.org/10.1080/17524030701334342.

Waltner-Towes, D., Kay, J. and Lister, N. M., eds. (2008). The ecosystem approach, complexity, uncertainty and managing for sustainability. New York, NY, U.S.A.: Columbia University Press.

URL: https://www.jstor.org/stable/10.7312/walt13250.5.

Weber, A. (5th August 2016). 'Twice as many Hector's dolphins as previously thought'. Radio NZ. URL: https://www.radionz.co.nz/news/national/310180 /twice-as-many-hector's-dolphins-as-previously-thought. 
Wilson, D. C. (2009). The paradoxes of transparency: science and the ecosystem approach to fisheries management in Europe. Amsterdam, The Netherlands: Amsterdam University Press.

URL: http: //www . oapen . org/search?identifier $=340024$.

Wilson, D. C. and Jacobsen, R. (2013). 'Analyzing resilience with communicative systems theory an example from European fisheries'. Maritime Studies 12 (1), p. 1. https://doi.org/10.1186/2212-9790-12-1.

World Wildlife Fund (2019). Hector's dolphin facts.

URL: https://www.worldwildlife.org/species/hector-s-dolphin.

Authors

Anna Palliser is Lecturer in Environmental Management, Southern Institute of Technology, New Zealand. E-mail: anna.palliser@sit.ac.nz.

Giles Dodson is Senior Lecturer in Writing Studies, Massey University, New Zealand. E-mail: g.dodson@massey.ac.nz.

How to cite

Palliser, A. and Dodson, G. (2019). 'Avoiding post-truth environmental conflict in New Zealand: communicating uncertainties in endangered species science'. JCOM 18 (04), A05. https:/ / doi.org/10.22323/2.18040205. 